\title{
Sr in coccoliths of Scyphosphaera apsteinii: partitioning behavior and role in coccolith morphogenesis
}

Erin M. Meyer ${ }^{\mathrm{a}}$, Gerald Langer ${ }^{\mathrm{b}}$, Colin Brownlee ${ }^{\mathrm{b}, \mathrm{c}}$, Glen L. Wheeler ${ }^{\mathrm{b}}$ \& Alison R. Taylor ${ }^{\mathrm{a}}$

a Department of Biology and Marine Biology, University of North Carolina Wilmington, Wilmington, NC, 28403, USA.

${ }^{b}$ Marine Biological Association, The Laboratory, Citadel Hill, Plymouth, Devon PL1 2PB, UK.

'School of Ocean and Earth Science, University of Southampton, Southampton, SO14 3ZH, UK.

Correspondence:

Alison R. Taylor - taylora@uncw.edu, corresponding author.

Erin M. Meyer - emm5468@uncw.edu

Gerald Langer - gerlan@mba.ac.uk 


\begin{abstract}
Coccolithophores are important contributors to global calcium carbonate through their species-specific production of calcite coccoliths. Nannofossil coccolith calcite remains an important tool for paleoreconstructions through geochemical analysis of isotopic and trace element incorporation including $\mathrm{Sr}$, which is a potential indicator of past surface ocean temperature and productivity. Scyphosphaera apsteinii (Zygodiscales) exhibits an unusually high $\mathrm{Sr} / \mathrm{Ca}$ ratio and correspondingly high partitioning coefficient $\left(\mathrm{D}_{\mathrm{Sr}}=2.5\right)$ in their two morphologically distinct types of coccoliths. Whether or not this reflects mechanistic differences in calcification compared to other coccolithophores is unknown. We therefore examined the possible role of $\mathrm{Sr}$ in $\mathrm{S}$. apsteinii calcification by growing cells in deplete, ambient, and higher than ambient Sr conditions (between 0.33 - $140 \mathrm{mmol} / \mathrm{mol} \mathrm{Sr} / \mathrm{Ca}$ ). The effects on growth, quantum efficiency of photosystem II (Fv/Fm), coccolith morphology, and calcite $\mathrm{D}_{\text {Sr }}$ were evaluated. No effect on $S$. apsteinii growth rate or Fv/Fm was observed when cells were grown in $\mathrm{Sr} / \mathrm{Ca}$ between 0.33-36 mmol/mol. However, at $72 \mathrm{mmol} / \mathrm{mol} \mathrm{Sr} / \mathrm{Ca}$ growth rate was significantly reduced, although Fv/Fm was unaffected. At $140 \mathrm{mmol} / \mathrm{mol}$ cultures failed to grow. Reducing the $\mathrm{Sr} / \mathrm{Ca}$ from ambient $(9 \mathrm{mmol} / \mathrm{mol})$ did not significantly alter the frequency of malformed and aberrant muroliths and lopadoliths, but at higher than ambient $\mathrm{Sr} / \mathrm{Ca}$ conditions coccolith morphology was significantly disrupted. This implies that $\mathrm{Sr}$ is not a critical determining factor in normal coccolith calcite morphology in this dimorphic species. Using electron dispersive spectroscopy (EDS) we observed an increase in $[\mathrm{Sr}]$ and decrease in $\mathrm{D}_{\mathrm{Sr}}$ of coccoliths as the $\mathrm{Sr} / \mathrm{Ca}$ of the growth medium increased. Interestingly, muroliths had significantly lower $\mathrm{Sr} / \mathrm{Ca}$ than lopadoliths at ambient and elevated [Sr], and lopadolith tips had lower Sr than bases in ambient conditions. In summary, the Sr fractionation behavior of $S$. apsteinii is unusual because of an overall high $\mathrm{D}_{\mathrm{Sr}}$, and an inter- and intra-coccolith variability in
\end{abstract}


$\mathrm{Sr} / \mathrm{Ca}$. We hypothesize that differential Sr-and Ca-binding capacity of coccolith associated polysaccharides may account for the unusual $\mathrm{Sr}$ fractionation of this species which can explain all observations made in this study. 


\subsection{Introduction}

Coccolithophores are unicellular marine algae that produce $\mathrm{CaCO}_{3}$ plates (coccoliths) intracellularly that are secreted onto the cell surface where they collectively form the calcite coccosphere (Young et al., 1999). Coccolithophores contribute roughly half of global $\mathrm{CaCO}_{3}$ production, producing 1-1.42 $\mathrm{Gt} \mathrm{C} \mathrm{yr}^{-1}$ (Daniels et al., 2018; Hopkins and Balch, 2018; Milliman, 1993). Therefore, coccolithophores have a significant impact on ocean biogeochemical cycles through calcification, photosynthesis, and ultimately carbon export (Balch, 2018; Krumhardt et al., 2017; Taylor et al., 2017). Nannofossil coccolith calcite is widely used in micropaleontology, biostratigraphy, and for paleo-reconstructions of ocean ecosystem dynamics (Flores et al., 1997; Saavedra-Pellitero et al., 2017; Stoll et al., 2007a; Stoll et al., 2007b; Young et al., 2014). This is partly due to their distinct morphologies, but also because stable isotope and cation fractionation in coccolith calcite provides tools that can aid paleoreconstructions of oceanic conditions at the time of precipitation.

Past studies have found detectable amounts of strontium $(\mathrm{Sr})$ in coccoliths (Hermoso et al., 2017; Rickaby et al., 2002; Stoll et al., 2002b), and ${ }^{88 / 86} \mathrm{Sr}$ isotope ratios (seawater:calcite) have been used to model past seawater temperature, Sr cycling, and carbonate chemistry (Muller et al., 2018). Calcite $\mathrm{Sr} / \mathrm{Ca}$ ratios have also been examined in relation to coccolithophore growth and calcification rates as a measure of ocean productivity. Stoll et al. (2007b) used coccoliths from sediment traps to determine species-specific $\mathrm{Sr} / \mathrm{Ca}$ ratios, which could then be used to estimate seasonal fluxes of $\mathrm{CaCO}_{3}$ export. Rickaby et al. (2002) found a positive relationship between growth rate and the Sr incorporation for Emiliania huxleyi grown under nitrogen 
limitation. Sr incorporation into coccoliths also increased with increased rates of calcification and carbon fixation (Rickaby et al., 2002). However, light induced changes in growth- and calcification rate did not affect Sr partitioning (Langer et al., 2006; Stoll et al., 2002a; Stoll et al., 2002b). Therefore growth and calcification rate per se do not influence Sr partitioning, but some physiological processes altered by nitrogen limitation do (Langer et al., 2006). Through understanding the relationship between Sr incorporation and carbon-specific growth rate, Rickaby et al. (2002) suggested $\mathrm{Sr} / \mathrm{Ca}$ ratios and $\varepsilon_{\mathrm{p}}$ (the difference in $\delta^{13} \mathrm{C}$ between dissolved inorganic carbon and organic matter) in coccolithophores could be used as a potential proxy for past surface $p \mathrm{CO}_{2}$ levels. Variations in cation incorporation can also suggest evolutionary links between extinct and extant coccolithophore species. Based on lower $\mathrm{Sr} / \mathrm{Ca}$ ratios, Sucheras-Marx et al. (2016) inferred that the mid-Jurassic Watznaueria britannica might have been adapted for oligotrophic waters, with slower growth rates than modern equivalent species.

Coccolithophores require one of the highest $\mathrm{Ca}^{2+}$ fluxes across the plasma membrane in order to sustain calcification (Brownlee and Taylor, 2004; Brownlee et al., 2015; Taylor et al., 2017), and have multiple modes of $\mathrm{Ca}^{2+}$ selective transport both into the cell and to various organelles and compartments (Hermoso, 2014; Mackinder et al., 2010; Marsh, 2003; Outka and Williams, 1971). Because $\mathrm{Sr}^{2+}$ has a similar electron configuration and chemical properties to $\mathrm{Ca}^{2+}$, it can potentially enter the cell through $\mathrm{Ca}^{2+}$ transporter proteins or channels with a relatively high $\mathrm{Sr}$ permeability. Indeed, $\mathrm{Sr}^{2+}$ has been used as $\mathrm{Ca}^{2+}$ analogue to trace the $\mathrm{Ca}^{2+}$ transport pathway in E. huxleyi (Gal et al., 2017). Multiple studies have calculated partitioning coefficients $\left(\mathrm{D}_{\mathrm{Sr}}\right)$ from coccolith $\mathrm{Sr} / \mathrm{Ca}$ ratios (Hermoso et al., 2017; Langer et al., 2006; Stevenson et al., 2014; Stoll et al., 2007b; Sun et al., 2018) resulting in $\mathrm{D}_{\mathrm{Sr}}$ values varying between $0.02-0.6$ for various coccolithophore species including E. huxleyi, Gephyrocapsa 
oceanica, and Coccolithus pelagicus. Scyphosphaera apsteinii is notable for its massive barrellike lopadoliths and ovoid muroliths that have an unusually high $\mathrm{Sr} / \mathrm{Ca}$ ratio of $22.1 \mathrm{mmol} / \mathrm{mol}$ (Drescher et al., 2012; Hermoso et al., 2017). The resulting $\mathrm{D}_{\mathrm{Sr}}$ of 2.5 (Hermoso et al., 2017), is an order of magnitude greater than other extant species, implying mechanistic differences in calcite production in S.apsteinii that leads to increased $\mathrm{Sr} / \mathrm{Ca}$ at the site of calcification and the coccolith. One such mechanistic difference could be that CAP functionality in S. apsteinii requires unusually high $\mathrm{Sr}$ levels in the coccolith vesicle. It was shown that CAP functionality depends on a certain cation composition of the calcifying fluid (Henriksen and Stipp, 2009). We hypothesize that the high $\mathrm{Sr} / \mathrm{Ca}$ of $S$. apsteinii coccoliths is required for normal morphogenesis, either directly in the calcite lattice or indirectly through an association with CAP. To test this hypothesis we grew S. apsteinii in Aquil media containing a range of Sr concentrations (3.3 -720 $\mu \mathrm{M}$, for reference, normal seawater has $90 \mu \mathrm{M}$ Sr, De Villiers, 1999), and analyzed coccolith morphology and $\mathrm{Sr} / \mathrm{Ca}$ ratios.

Based on the idea that $\mathrm{Sr}^{2+}$ takes the same cellular route as $\mathrm{Ca}^{2+}$ (see above), a conceptual model describes Sr partitioning in coccolithophores as a steady state scenario (Langer et al., 2006). In its simplest form this model predicts an even distribution of $\mathrm{Sr}$ in the coccolith. Indeed, previous studies on different species suggest an even distribution of Sr (Grovenor et al., 2006; Prentice et al., 2014; Sucheras-Marx et al., 2016). However, the investigated species display coccolithophore-typical Sr partitioning behavior, i.e. have a much lower $\mathrm{Sr} / \mathrm{Ca}$ than S. apsteinii. We hypothesize that the atypical Sr partitioning of S. apsteinii might include non-uniform $\mathrm{Sr}$ distribution within the coccoliths, and differences in $\mathrm{Sr} / \mathrm{Ca}$ between the morphologically distinct lopadoliths and muroliths. To test these hypotheses, we performed analytical scanning electron microscopy (SEM) combined with electron dispersive spectroscopy (EDS). 


\subsection{Methods}

\subsection{Maintenance of algal cultures, experimental media, and growth conditions}

S.apsteinii strain RCC 1456 was obtained from the Roscoff Culture Collection, France. Batch cultures were maintained in sterile $40 \mathrm{~mL}$ polystyrene flasks in a modified $\mathrm{L} 1$ medium (LH; Fowler et al., 2015) comprising autoclaved and filter sterilized Gulf Stream seawater, amended with LH nutrients and vitamins. The [Sr] of the seawater was $95.4 \mu \mathrm{M} \mathrm{Sr}$ as determined using ICP-MS, which is expected for seawater. Experimental cultures were grown in Aquil media, modified from (Kester et al., 1967) by adding f/8 metals, f/ 8 vitamins, $1 \mathrm{~mL} / \mathrm{L}$ of sterilized Gulf Stream seawater, and modifying the following nutrients: $64 \mu \mathrm{M} \mathrm{NO}_{2}^{-}, 4 \mu \mathrm{M} \mathrm{PO}_{4}{ }^{3}$, and $10 \mathrm{nM} \mathrm{SeO}$. The [ $\mathrm{Sr}]$ of the Aquil medium was $3.3 \mu \mathrm{M}$ as determined using ICP-MS. A $1 \mathrm{M}$ $\mathrm{SrCl}_{2} \cdot 6 \mathrm{H}_{2} \mathrm{O}$ stock solution (Puratronic, 99.9965\%, 10877, Alfa Aesar) was used for amending the [Sr] of the Aquil media from 3.3 (no added Sr), to 90, 360, and $720 \mu \mathrm{M}$ Sr. The cells were acclimated for at least 8 generations in the corresponding Aquil/Sr medium to ensure all attached coccoliths were produced in the presence of the treatment [Sr]. All cultures were maintained at $15^{\circ} \mathrm{C}$ on a $14: 10 \mathrm{~h}$ light:dark cycle, at approximately $100 \mu \mathrm{mol} \mathrm{m}^{-2} \mathrm{~s}^{-1}$ with sub-culturing at midlate exponential growth phase.

Cultures acclimated to each $[\mathrm{Sr}]$ treatment were harvested at mid-exponential growth and used to establish four replicate experimental flasks with a starting density of $\sim 1 \times 10^{3}$ cells $\mathrm{mL}^{-1}$. Cell counts were recorded over $10 \mathrm{~d}$ using a Sedgewick-Rafter chamber with a minimum of 300 cells counted per sample. Cell densities were plotted versus time and growth rate $(\mu)$ was calculated from exponential regression including all data-points till harvest day (day 10). 
The quantum yield of photosystem II $\left(\mathrm{F}_{\mathrm{v}} / \mathrm{F}_{\mathrm{m}}\right)$ was estimated using an AquaPen AP 100 fluorometer (PSI, Drasov, Czech Republich). Approximately $1.5 \mathrm{~mL}$ of sample from each flask was placed in a cuvette and dark-adapted at room temperature for $15 \mathrm{~min}$ prior to measurements. An average of 3 measurements was taken over 3 min with cuvettes gently inverted to resuspend cells $10 \mathrm{~s}$ prior to each measurement.

\subsection{SEM and EDS}

Mid-exponential S. apsteinii cells were used for SEM and EDS analysis. A $1.5 \mathrm{~mL}$ aliquot of each replicate culture for each $[\mathrm{Sr}]$ treatment was syringe filtered onto $13 \mathrm{~mm} 0.4 \mu \mathrm{m}$ Isopore filters [Merck Millipore Ltd.] followed by buffered Nanopure water (1 mM HEPES, pH 8.0) to remove salts. Filters were air-dried and mounted onto an aluminum stub with carbon adhesive tabs before coating with $10 \mathrm{~nm}$ Pt/Pd. Samples were analyzed using a FEI Verios 460L SEM equipped with an Oxford Xmax silicon drift EDS detector and AZtec acquisition and analysis software (Oxford Instruments, UK). The primary beam acceleration was $10 \mathrm{kV}$ (EDS and electron backscatter imaging mode) or $2 \mathrm{kV}$ (secondary electron imaging). For EDS, spectra were from 1-2 $\mu \mathrm{m}$ diameter regions of interest collecting for $60 \mathrm{~s}$ between $2,000-8,000 \mathrm{cps}$ with an average deadtime $<5 \%$. Peaks for major elements of coccoliths were auto-detected and Pt/Pd peaks were eliminated. Standardless quantification was used to estimate atomic \% (At\%) and weight $\%(\mathrm{Wt} \%)$ compositions of calcite. A power analysis suggested a minimum sample size of 12 was needed to statistically detect an effect size of $\geq 0.15 \mathrm{At} \%$ Sr. Therefore, at least 31 spectra were taken for muroliths and at the base and tip of each lopadolith. Wt\% values were used to determine $\mathrm{Sr} / \mathrm{Ca} \mathrm{mmol} / \mathrm{mol}$ of calcite (Hermoso et al., 2017) which were subsequently used to calculate $\mathrm{D}_{\mathrm{Sr}}$ (Eq. 2). 
Eq 1: $\frac{S r m m o l}{C a m o l}=1000 * \frac{S r[W t \%]}{C a[W t \%]} * \frac{C a M W}{S r M W}$

Eq 2: $D_{S r}=\frac{\text { Sr } / \text { Ca mineral }}{\text { Sr/Ca medium }}$

Effects of [Sr] on coccolith morphology were determined by scoring coccoliths from 40 cells for each treatment. Coccoliths were only scored if the majority of the coccolith could be seen. Muroliths were scored into four categories: normal, malformed, incomplete, and aberrant (see Fig 2). Lopadoliths were scored into five categories: normal, malformed (minor malformations commonly seen in control cultures), Type S (incomplete, normal calcite morphology), Type R (longitudinal cleavage in lopadoliths), and Type T (aberrant, completely disorganized calcite; see Fig 2). Scores for each morphometric category are presented as the average of the experimental replicates $(n=4)$.

\subsection{Statistics}

A one-way ANOVA was completed in SigmaPlot 14.0 to compare differences in morphology between Sr treatments. The data was found to be not normal through a ShapiroWilks test, therefore we used a Tukey's pairwise comparison. A t-test was used for comparing growth rates, $\mathrm{Sr} / \mathrm{Ca} \mathrm{mmol} / \mathrm{mol}, \mathrm{D}_{\mathrm{sr}}$, and differences in $\mathrm{Sr}$ content between muroliths and lopadoliths. The data was found to be not normal through a Shapiro-Wilks test, therefore we used a Mann-Whitney Rank Sum test. Differences between Sr content in lopadolith bases and tips were analyzed using a Student's t-test.

\subsection{Results}

\subsection{Sr effects on physiology and coccolith morphology}


There was no significant effect of low Sr on growth rate and photosynthetic physiology (Fig. 1A-B); however, cells grown in $72 \mathrm{mmol} / \mathrm{mol} \mathrm{Sr} / \mathrm{Ca}$ had significantly lower growth rates (p $<0.01$; Fig1A). Cells grown in $144 \mathrm{mmol} / \mathrm{mol} \mathrm{Sr} / \mathrm{Ca}$ stopped dividing almost immediately after exposure, implying a potential Sr toxicity, and were not further analyzed (data not shown). Average $\mathrm{F}_{\mathrm{v}} / \mathrm{F}_{\mathrm{m}}$ values ranged from $0.55-0.58$ and were unaffected by [Sr] over the range 0.33 $72 \mathrm{mmol} / \mathrm{mol} \mathrm{Sr} / \mathrm{Ca}$, indicating there was no overall physiological cell stress due to either lower or higher than ambient Sr (Fig. 1B). The average Sr/Ca in S. apsteinii coccolith calcite was three times that of the ambient medium $(27.0 \pm 10.8 \mathrm{vs} 9 \mathrm{mmol} / \mathrm{mol}$; Figure $1 \mathrm{C}-\mathrm{D})$. Coccolith calcite Sr/Ca significantly increased with increasing media [Sr] (p < 0.001; Fig. 1C-D; Table 1) although the corresponding $\mathrm{D}_{\mathrm{Sr}}$ decreased with the relationship best described as a second-order polynomial curve $\left(\mathrm{r}^{2}=0.92 ; \mathrm{p}<0.001\right.$; Table 1$)$.

Coccolithogenesis was disrupted when S. apsteinii were grown in higher than ambient [Sr], resulting in increased frequency of malformed and aberrant coccoliths (Fig. 2). The 0.33 $\mathrm{mmol} / \mathrm{mol}$ group had the highest frequency of normal coccoliths $(\mathrm{p}<0.001)$ and fewest morphological disruptions to their coccoliths (Fig. 2; Fig. 3), while the $72 \mathrm{mmol} / \mathrm{mol}$ group had significantly more Type $\mathrm{R}(\mathrm{p}<0.001)$ and Type $\mathrm{T}(\mathrm{p}<0.05)$ lopadolith malformations and aberrant muroliths ( $<<0.001$; Fig. 3; Table 2). Type R coccoliths were seen frequently in response to elevated Sr concentrations, showing jagged edges along the lopadolith tips (Fig. 2; Fig. 3).

3.2 Sr/Ca and $D_{S r}$ correlates with Sr/Ca of medium and varies between and within coccolith types

When comparing cells grown at ambient [Sr], we observed muroliths had significantly less Sr than lopadoliths $(22.9 \pm 10.6$ and $31.1 \pm 9.5 \mathrm{Sr} / \mathrm{Ca} \mathrm{mmol} / \mathrm{mol}$ respectively; $\mathrm{p}<0.001$; Fig. 
4). The lower murolith Sr content was consistent among all [Sr] treatments analyzed (Fig. 4; Table 2). Correspondingly, $\mathrm{D}_{\mathrm{Sr}}$ for muroliths was significantly lower than lopadoliths across all [Sr] treatments $(\mathrm{p}<0.001$; Table 2). The limit of detection for Sr using EDS was determined to be $0.2 \mathrm{Wt} \%$ (2.29 $\mathrm{mmol} / \mathrm{mol})$. The $\mathrm{Sr} / \mathrm{Ca}$ values for coccoliths grown in the $0.33 \mathrm{mmol} / \mathrm{mol}$ $\mathrm{Sr} / \mathrm{Ca}$ treatment were clearly much lower than the other treatments, but considered to be below the technical LOD and not reported here, although the technical LOD is indicated on relevant graphs.

Because of the large size of $S$. apsteinii coccoliths, the spatial distribution of $\mathrm{Sr}$ in lopadoliths was examined by acquiring EDS estimates of $\mathrm{Sr} / \mathrm{Ca}$ from base and tip regions of these barrel-like structures. Lopadolith tips had a small but significantly lower Sr incorporation compared to bases in cells grown in ambient $[\mathrm{Sr}](28.8 \pm 9.87$ and $33.6 \pm 8.51 \mathrm{Sr} / \mathrm{Ca} \mathrm{mmol} / \mathrm{mol}$ respectively; $\mathrm{p}<0.05$; Fig. 5) although the calculated $\mathrm{D}_{\mathrm{Sr}}$ values were lower but not significant $(\mathrm{p}=0.05)$ between tip and base. The spatial difference in $\mathrm{Sr} / \mathrm{Ca}$ between base and tip was not significantly different in cells grown at higher than ambient [Sr] (Fig. 4; Table 2).

\subsection{Discussion}

\subsection{Fractionation for $\mathrm{Sr}$ in $\mathrm{S}$. apsteinii}

Our results are consistent with Hermoso et al. (2017) in that there is unusually high $\mathrm{Sr} / \mathrm{Ca}$ in S. apsteinii calcite compared to other species. We also observed an increase in coccolith $\mathrm{Sr} / \mathrm{Ca}$ and a decrease in $\mathrm{D}_{\text {Sr }}$ with increasing media Sr concentrations, which is in line with several studies (Hermoso et al., 2017; Payne et al., 2008; Sun et al., 2018). A range of Sr/Ca ratios in coccolithophores has been reported (Prentice et al., 2014; Stoll et al., 2002b; Stoll et al., 2007b) with a trend for small coccolithophores such as E. huxleyi and G. oceanica significantly 
fractionating against $\mathrm{Sr}$, yielding $\mathrm{Sr} / \mathrm{Ca}$ ratios of $\sim 3$ and $1.2 \mathrm{mmol} / \mathrm{mol}$ respectively (Hermoso et al., 2017; Stoll et al., 2002a). This relationship appears to also hold true for mixed field samples in which sediments with an abundance of larger species bearing bulky coccoliths such as Calcidiscus leptoporus are associated with higher $\mathrm{Sr} / \mathrm{Ca}$ ratios (between 2 and $2.4 \mathrm{mmol} / \mathrm{mol}$ ) than sediments dominated by smaller species such as E.huxleyi (Stoll and Schrag, 2000). The $\mathrm{D}_{\mathrm{Sr}}$ in S.apsteinii at ambient [ $\mathrm{Sr}]\left(\mathrm{D}_{\mathrm{Sr}}=3\right.$, this study) is similarly much higher when compared to other species such as E.huxleyi (0.1-0.6; Langer et al., 2006; Muller et al., 2018; Rickaby et al., 2002; Stevenson et al., 2014), G.oceanica (0.14 - 0.34; Hermoso et al., 2017; Stevenson et al., 2014), and C. braarudii (0.31 - 0.43; Muller et al., 2018; Stevenson et al., 2014).

To explain the unusually high Sr/Ca ratio in S.apsteinii, Hermoso et al. (2017) proposed a multi-step cellular process whereby $\mathrm{Ca}^{2+}$ channels in the plasma membrane fractionate in favor of $\mathrm{Sr}$ with additional fractionation for $\mathrm{Sr}$ through intracellular $\mathrm{Ca}^{2+}$ transport through an unexplained mechanism. $\mathrm{A} \mathrm{Ca}^{2+}$ return flux from the $\mathrm{CV}$ into the cytosol through $\mathrm{Ca}^{2+}$ channels is also proposed to fractionate against $\mathrm{Sr}$, further enriching $\mathrm{Sr}$ at the site of mineralization. We offer several additional perspectives to interpret the high Sr content observed in S. apsteinii coccoliths.

Fractionation of plasmamembrane $\mathrm{Ca}^{2+}$ channels for $\mathrm{Sr}^{2+}$ as proposed by Hermoso et al. (2017) could explain the high $\mathrm{D}_{\mathrm{Sr}}$ of $S$. apsteinii. In fact, a higher $\mathrm{Sr}^{2+}$ permeability $\left(\mathrm{Sr}^{2+}>\mathrm{Ca}^{2+}\right)$ has been demonstrated in animal systems for R- and L-Type $\mathrm{Ca}^{2+}$ channels, such as $\mathrm{Ca}_{\mathrm{v}} 1.3$ (Bourinet et al., 1996; Rodriguez-Contreras et al., 2008; Rodriguez-Contreras and Yamoah, 2003). This scenario implies that $\mathrm{Ca}^{2+}$ channels in S. apsteinii have a different $\mathrm{Sr}$ fractionation behavior (i.e. relative permeability) than channels in other coccolithophores studied so far. While this is possible it would have to be a specific feature of the Pontosphaeraceae (or even 
Scyphosphaera) because Helicosphaera carteri (also a member of the Zygodiscales) displays a fractionation against $\mathrm{Sr}$, similar to the studied Coccolithales and Isochrysidales (Stoll et al., 2007b). As critical data on coccolithophore $\mathrm{Ca}^{2+}$ channels is lacking, future work should assess the permeability of these channels to $\mathrm{Sr}^{2+}$. Additionally, using published calcification rates (Gafar et al., 2019), we calculate that S.apsteinii exhibit over twice the calcification rate of E.huxleyi when normalized to cell surface area $\left(0.45 \mathrm{pg} / \mu \mathrm{m}^{2} / \mathrm{d}\right.$ vs $0.18 \mathrm{pg} / \mu \mathrm{m}^{2} / \mathrm{d}$, respectively). Production of large, bulky S.apsteinii coccoliths therefore requires over twice the flux of $\mathrm{Ca}^{2+}$ per unit membrane surface area than E.huxleyi. The higher calcification rates combined with lower cation selectivity for $\mathrm{Ca}^{2+}$ transporters could contribute to the increased $\mathrm{Sr} / \mathrm{Ca}$ relative to seawater in S.apsteinii coccoliths.

There are, however, alternative explanations for the high $\mathrm{D}_{\mathrm{Sr}}$ in S. apsteinii. Amorphous calcium carbonate (ACC) favors trace metal ( $\mathrm{Sr}$ ) incorporation into the crystal lattice structure in inorganic systems (Littlewood et al., 2017). Higher than expected Sr incorporation could theoretically be explained if S. apsteinii utilizes an ACC precursor phase for calcite precipitation. Although an ACC precursor is used in many biomineralization systems such as in foraminifera and mollusk shell formation (Addadi et al., 2006; De Nooijer et al., 2014), and has been considered as a possible intermediate in coccolithophore calcification (Brownlee et al., 2015), there is no current evidence for its use in coccolithophore biomineralization. Moreover, the hypothesis that S. apsteinii uses ACC while other coccolithophores do not, implies species specific differences in calcification mechanisms at a basic level (mode of calcium carbonate precipitation).

A more parsimonious explanation is differences in calcification mechanisms at a higher level, such as species-specific coccolith associated polysaccharides (CAP; Fichtinger-Schepman 
et al., 1981; Marsh et al., 2002). CAP play an important role in coccolith morphogenesis, mainly as inhibitors of crystal growth (Borman et al., 1982; Marsh, 1994; Westbroek et al., 1984). An inorganic study found that when using malonic acid to mimic the function of CAP by blocking acute calcite kink sites, $c$-axis elongation occurred as similarly seen in heterococcoliths (Payne et al., 2008). While species-specific CAP are likely playing the same functional role, their precise involvement in determining crystal growth and morphology could be subtly different among species. For example, some CAP influence crystal morphology by site-specific attachment to crystallographic steps (Henriksen et al., 2004), but others might not. S. apsteinii have CAP that are known to differ from those of some placolith bearing species, such as C. braarudii (Walker et al., 2018a). We propose that the difference in CAP between S. apsteinii and other species could contribute to different $\mathrm{Sr}$ fractionation behavior in at least three ways: 1) intra coccolith vesicle CAP could alter the vesicle $\mathrm{Ca}^{2+}$ concentration needed to achieve super-saturation, which would in turn affect $\mathrm{Sr}$ fractionation (Langer et al., 2006). 2) Different CAP might have different $\mathrm{Sr}$ binding capacity or requirements, akin to brown algae polysaccharides (Davis et al. 2003), which might influence coccolith vesicle $\mathrm{Sr} / \mathrm{Ca}$. Such a mechanism is supported by inorganic experiments in which growing calcite crystals exposed to increasing [malonic acid] resulted in higher Sr incorporation. As this process mimics CAP-Sr interactions, it could explain the variable Sr incorporation seen among coccolithophore species (Payne et al., 2008). 3) Incorporation of CAP itself within coccoliths could introduce an organic phase with an interspecific Sr/Ca. Because different kinds of CAP are used for different (partly morphogenetic) purposes (Marsh, 2000; Walker et al., 2018a), CAP-specific Sr fractionation offers a good explanation for inter as well as intra (see below) specific differences in Sr fractionation. Overall, 
we conclude that CAP likely influence $\mathrm{Sr}$ fractionation and there are several ways in which this could happen.

\subsection{Variable inter- and intra- coccolith Sr fractionation in S.apsteinii}

The different Sr fractionation between muroliths and lopadoliths, and spatially within lopadoliths, was unexpected. Secondary ion mass spectroscopy analysis of extant and microfossil placolith-bearing species such as $C$. braarudii and Reticulofenestra bisecta demonstrates spatially uniform minor element distribution (Grovenor et al., 2006; Prentice et al., 2014; Sucheras-Marx et al., 2016). This is in accordance with the prediction of a conceptual model (in its simplest form) describing Sr fractionation in E. huxleyi (Langer et al., 2006). A refined version of the model considers the effect of species-specific CAP-related Sr fractionation but does not consider coccolith type-specific fractionation, let alone intra coccolith variability in CAP influence (Langer et al., 2006). We propose that the model by Langer et al. (2006) is modified to incorporate a non-constant CAP factor within any given species. Applying the concept of a non-constant CAP factor, both coccolith type-specific and intra coccolith positionspecific Sr fractionation can be accounted for. We propose that S. apsteinii uses different CAP for murolith and lopadolith formation respectively, as well as for lopadolith bases and tips.

Another advantage of the "CAP-hypothesis" is that it can potentially explain why $\mathrm{D}_{\mathrm{Sr}}$ in S. apsteinii decreases with increasing seawater [Sr] (Table 2B): The resulting high coccolith vesicle $\mathrm{Sr} / \mathrm{Ca}$ could possibly change CAP structure/conformation (Ishii et al., 1999; Kucerka et al., 2008) in such a way that the $\mathrm{Ca}^{2+}$ binding capacity of CAP increases (Woodward and Davidson, 1968). This increased $\mathrm{Ca}^{2+}$ binding capacity will then increase the vesicle $\left[\mathrm{Ca}^{2+}\right]$ concentration needed to achieve super-saturation with respect to calcite, which will in turn decrease $\mathrm{D}_{\mathrm{Sr}}$ (Langer et al. 2006). 


\subsection{Sr is not required for morphogenesis in $\mathrm{S}$. apsteinii}

Because coccolith morphology was unaffected in S. apsteinii cells grown in a [Sr] that was over 25 -fold lower than ambient ( 0.33 vs $9 \mathrm{mmol} / \mathrm{mol})$, we conclude that $\mathrm{Sr}$ is not essential for coccolith morphogenesis of the unusually bulky coccoliths of this species. On the contrary, higher [Sr] resulted in significant disruption of normal crystal morphogenesis as evidenced by a dramatic increase in the number of aberrant coccoliths produced. The lower growth rates for coccolithophores grown in $72 \mathrm{mmol} / \mathrm{mol} \mathrm{Sr} / \mathrm{Ca}$, and the inability of cells to grow in media [Sr] above this, could be the result of a compromised coccosphere potentially impeding their ability to properly divide. A similar effect was observed in C. pelagicus in which calcification was disrupted using three separate approaches; Low $\mathrm{Ca}^{2+}$, the metal chelator 1-hydroxyethane 1,1diphosphonic acid (HEDP), and the Si analogue Ge (Walker et al., 2018b).

\subsection{Why does high Sr/Ca disrupt S. apsteinii coccolith morphogenesis?}

The increased frequency of Type $\mathrm{R}$ malformations in response to the 36 and 72 $\mathrm{mmol} / \mathrm{mol} \mathrm{Sr} / \mathrm{Ca}$ treatments suggests the disruptive effect of high $\mathrm{Sr}$ on morphology is not purely through inorganic processes (Wasylenki et al., 2005). An inorganic mechanism of Sr-induced disruption would affect the whole coccolith, but Type R malformations are extremely site specific and leave most of the coccolith unaffected. Furthermore it is unlikely that aberrant coccoliths are the result of high Sr interfering with the cytoskeleton otherwise cell division and growth rate would be affected (Durak et al., 2017; Langer et al., 2010), which is not the case at $36 \mathrm{mmol} / \mathrm{mol} \mathrm{Sr} / \mathrm{Ca}$. Alternatively, as discussed above, CAP profoundly influence coccolith morphology (Borman et al., 1982). CAP bind divalent cations and their morphogenetic function depends on the ionic composition of the fluid (Davis et al., 2003; Grant et al., 1973; Henriksen 
and Stipp, 2009). Possibly high $\mathrm{Sr} / \mathrm{Ca}$ changes CAP structure/conformation (Ishii et al., 1999;

Kucerka et al., 2008) which impairs their morphogenetic function (Henriksen and Stipp, 2009).

\subsection{Concluding Remarks}

S. apsteinii shows a weak $\mathrm{Sr}$ fractionation (high $\mathrm{D}_{\mathrm{Sr}}$ ) in their calcite coccoliths that is significantly higher than that of any coccolithophore (extant or extinct) for which $\mathrm{Sr} / \mathrm{Ca}$ has been determined. Our results show that $\mathrm{Sr}$ is not necessary for normal murolith or lopadolith morphogenesis. However, elevated levels of Sr in the medium disrupt coccolith morphogenesis and ultimately cell division likely due to an incomplete coccosphere. We show that S. apsteinii fractionates Sr differently between and within coccolith types, suggesting Sr incorporation is not solely governed by a simple steady state $\mathrm{Sr}$ - and Ca flux to the CV. A variety of species-specific $\mathrm{CAP}$ that regulate morphogenesis may underlie the spatial and morphologically distinct $\mathrm{Sr}$ fractionation. Although $\mathrm{Sr} / \mathrm{Ca}$ in coccoliths has been used to reconstruct past coccolithophore productivity, the coccolithophore $\mathrm{Sr} / \mathrm{Ca}$ proxy remains poorly understood. Our study implies that inter-and intraspecific organic phases play a critical role in minor element incorporation into coccoliths and therefore need to be considered when developing a mechanistic understanding of proxy relationships.

\section{Acknowledgements}

We thank Dr. Jack Pender at Eastern Carolina University for running seawater Sr analysis using ICP-MS. The work was supported by NSF GEO-NERC grant 1638838 to ART and by Natural Environment Research Council grant NE/N011708/1. Analytical electron microscopy was performed in part at 1) Analytical Instrumentation Facility (AIF) at North Carolina State 
University, supported by the State of North Carolina and the National Science Foundation

(award number ECCS-1542015) and 2) Joint School of Nanoscience and Nanoengineering, a

member of the Southeastern Nanotechnology Infrastructure Corridor (SENIC) and National

Nanotechnology Coordinated Infrastructure (NNCI), which is supported by the National Science

Foundation (Grant ECCS-1542174).

ERC

\section{Tables and Figures}

Table 1 S.apsteinii murolith (A) and lapodolith (B) morphology in response to Sr. The morphology of coccoliths from 10 cells per replicate flask for each Sr treatment were scored under an SEM. Scores for each morphometric category are presented as the average of the experimental replicated $(n=4)$. Type $S$ : an incomplete lopadolith with normal calcite morphology. Type R: a lopadolith with longitudinal cleavage. Type T: an aberrant lopadolith with completely disorganized calcite. Significantly more normal coccoliths were scored in the $0.33 \mathrm{mmol} / \mathrm{mol} \mathrm{Sr} / \mathrm{Ca}$ treatment $(\mathrm{p}<0.001)$, while more aberrant muroliths $(\mathrm{p}<0.001)$ and lopadoliths (Type R: $\mathrm{p}<$ 0.001; Type T: $\mathrm{p}<0.05)$ were scored in $72 \mathrm{mmol} / \mathrm{mol} \mathrm{Sr} / \mathrm{Ca}$.

A.

\begin{tabular}{|c|c|c|c|c|}
\hline $\begin{array}{c}\text { Media Sr/Ca } \\
(\mathrm{mmol} / \mathrm{mol})\end{array}$ & $\begin{array}{c}\text { Normal } \\
\text { Muroliths } \\
\text { [ } \pm \mathrm{sd}]\end{array}$ & $\begin{array}{l}\text { Incomplete } \\
\text { Muroliths } \\
{[ \pm \text { sd }]}\end{array}$ & $\begin{array}{c}\text { Malformed } \\
\text { Muroliths } \\
\quad[ \pm \mathrm{sd}]\end{array}$ & $\begin{array}{c}\text { Aberrant } \\
\text { Muroliths } \\
\text { [ } \pm \mathrm{sd}]\end{array}$ \\
\hline 0.33 & $\begin{array}{l}\mathbf{5 1 . 4} \\
{[7.8]}\end{array}$ & $\begin{array}{l}\mathbf{2 1 . 3} \\
{[8.0]}\end{array}$ & $\begin{array}{l}\mathbf{2 4 . 8} \\
{[3.8]}\end{array}$ & $\begin{array}{c}\mathbf{2 . 5} \\
{[2.3]}\end{array}$ \\
\hline 9 & $\begin{array}{l}\mathbf{4 4 . 3} \\
{[6.8]}\end{array}$ & $\begin{array}{l}\mathbf{2 0 . 3} \\
{[2.5]}\end{array}$ & $\begin{array}{l}32.2 \\
{[3.2]}\end{array}$ & $\begin{array}{c}\mathbf{3 . 3} \\
{[1.7]}\end{array}$ \\
\hline 36 & $\begin{array}{l}\mathbf{4 0 . 8} \\
{[4.2]}\end{array}$ & $\begin{array}{l}\mathbf{2 3 . 5} \\
{[1.7]}\end{array}$ & $\begin{array}{l}\mathbf{2 8 . 2} \\
{[3.2]}\end{array}$ & $\begin{array}{c}7.5 \\
{[6.8]}\end{array}$ \\
\hline 72 & $\begin{array}{l}\mathbf{1 6 . 2} \\
{[2.3]}\end{array}$ & $\begin{array}{l}\mathbf{2 9 . 0} \\
{[9.4]}\end{array}$ & $\begin{array}{c}\mathbf{3 7 . 4} \\
{[5.3]}\end{array}$ & $\begin{array}{l}\mathbf{1 7 . 4} \\
{[8.0]}\end{array}$ \\
\hline
\end{tabular}


B.

\begin{tabular}{cccccc}
\hline $\begin{array}{c}\text { Media Sr/Ca } \\
(\mathrm{mmol} / \mathrm{mol})\end{array}$ & $\begin{array}{c}\text { Normal } \\
\text { Lopadoliths } \\
{[ \pm \mathrm{sd}]}\end{array}$ & $\begin{array}{c}\text { Malformed } \\
\text { Lopadoliths } \\
{[ \pm \mathrm{sd}]}\end{array}$ & $\begin{array}{c}\text { Type } \mathrm{S} \\
\text { Lopadoliths } \\
{[ \pm \mathrm{sd}]}\end{array}$ & $\begin{array}{c}\text { Type } \mathrm{R} \\
\text { Lopadoliths } \\
{[ \pm \mathrm{sd}]}\end{array}$ & $\begin{array}{c}\text { Type } \mathrm{T} \\
\text { Lopadoliths } \\
{[ \pm \mathrm{sd}]}\end{array}$ \\
\hline \multirow{2}{*}{0.33} & $\mathbf{6 6 . 8}$ & $\mathbf{1 1 . 6}$ & $\mathbf{1 2 . 3}$ & $\mathbf{7 . 0}$ & $\mathbf{2 . 2}$ \\
& {$[12.7]$} & {$[9.0]$} & {$[3.3]$} & {$[3.4]$} & {$[2.6]$} \\
9 & $\mathbf{4 6 . 9}$ & $\mathbf{2 3 . 0}$ & $\mathbf{2 2 . 5}$ & $\mathbf{7 . 7}$ & $\mathbf{0 . 0}$ \\
& {$[3.5]$} & {$[4.7]$} & {$[5.5]$} & {$[7.3]$} & {$[0.0]$} \\
36 & $\mathbf{4 7 . 4}$ & $\mathbf{2 0 . 8}$ & $\mathbf{1 8 . 4}$ & $\mathbf{1 1 . 4}$ & $\mathbf{2 . 1}$ \\
& {$[12.3]$} & {$[10.1]$} & {$[9.4]$} & {$[3.0]$} & {$[4.2]$} \\
& & & & $\mathbf{3 4 . 9}$ & $\mathbf{1 1 . 9}$ \\
& $\mathbf{1 4 . 5}$ & {$[3.7$} & $\mathbf{1 8 . 0}$ & $\mathbf{3 4 . 9}$ & {$[9.6]$} \\
\hline
\end{tabular}


Table $2 \mathrm{Sr}$ incorporation (A) and partitioning coefficients (B) in S.apsteinii coccoliths from cells grown under ambient and high external [Sr]. The calcite $\mathrm{Sr} / \mathrm{Ca} \mathrm{mmol} / \mathrm{mol}$ ratio represents the amount of $\mathrm{Sr}$ relative to $\mathrm{Ca}$ in coccolith calcite, which significantly increases with increasing Sr media concentration $(\mathrm{p}<0.02)$. The $\mathrm{D}_{\mathrm{Sr}}$ is the $\mathrm{Sr}$ partitioning coefficient which exponentially decreases with increasing Sr media concentration $(\mathrm{p}<0.001)$. Note that for the $0.33 \mathrm{mmol} / \mathrm{mol} \mathrm{Sr} / \mathrm{Ca}$ treatment, EDS Sr was below the technical LOD and subsequent values were not determined.

A.

\begin{tabular}{ccccc}
\hline $\begin{array}{c}\text { Media Sr/Ca } \\
(\mathrm{mmol} / \mathrm{mol})\end{array}$ & $\begin{array}{c}\text { Calcite Sr/Ca } \\
(\mathrm{mmol} / \mathrm{mol}) \\
{[ \pm \mathrm{sd}]}\end{array}$ & $\begin{array}{c}\text { Murolith Sr/Ca } \\
(\mathrm{mmol} / \mathrm{mol}) \\
{[ \pm \mathrm{sd}]}\end{array}$ & $\begin{array}{c}\text { Lopadolith } \\
\text { Base Sr/Ca } \\
(\mathrm{mmol} / \mathrm{mol}) \\
{[ \pm \mathrm{sd}]}\end{array}$ & $\begin{array}{c}\text { Lopadolith } \\
\text { Tip Sr/Ca } \\
(\mathrm{mmol} / \mathrm{mol}) \\
{[ \pm \mathrm{sd}]}\end{array}$ \\
\hline 33 & $\mathrm{ND}$ & $\mathrm{ND}$ & $\mathrm{ND}$ & $\mathrm{ND}$ \\
& & & & \\
9 & $\mathbf{2 7 . 0}$ & $\mathbf{2 2 . 9}$ & $\mathbf{3 3 . 6}$ & $\mathbf{2 8 . 8}$ \\
& {$[10.8]$} & {$[10.6]$} & {$[8.51]$} & {$[9.87]$} \\
36 & $\mathbf{3 6 . 8}$ & $\mathbf{3 1 . 7}$ & $\mathbf{4 5 . 4}$ & $\mathbf{4 0 . 7}$ \\
& {$[18.3]$} & {$[16.7]$} & {$[16.3]$} & {$[19.2]$} \\
& $\mathbf{5 1 . 3}$ & $\mathbf{3 9 . 6}$ & $\mathbf{6 2 . 9}$ & $\mathbf{5 9 . 9}$ \\
& {$[27.1]$} & {$[23.4]$} & {$[24.8]$} & {$[23.3]$} \\
\hline
\end{tabular}




\begin{tabular}{|c|c|c|c|c|}
\hline $\begin{array}{c}\text { Media } \mathrm{Sr} / \mathrm{Ca} \\
(\mathrm{mmol} / \mathrm{mol})\end{array}$ & $\begin{array}{c}\mathrm{D}_{\mathrm{Sr}} \\
{[ \pm \mathrm{sd}]}\end{array}$ & $\begin{array}{l}\text { Murolith } D_{S r} \\
\qquad[ \pm \mathrm{sd}]\end{array}$ & $\begin{array}{c}\text { Lopadolith } \\
\text { Base } D_{S r} \\
{[ \pm \mathrm{sd}]} \\
\end{array}$ & $\begin{array}{c}\text { Lopadolith Tip } \\
\text { DSr } \\
{[ \pm \mathrm{sd}]} \\
\end{array}$ \\
\hline 0.33 & ND & ND & ND & ND \\
\hline 9 & $\begin{array}{c}\mathbf{3 . 0 0} \\
{[1.20]}\end{array}$ & $\begin{array}{c}\mathbf{2 . 5 4} \\
{[1.18]}\end{array}$ & $\begin{array}{c}\mathbf{3 . 7 4} \\
{[0.95]}\end{array}$ & $\begin{array}{l}\mathbf{3 . 2 0} \\
{[1.10]}\end{array}$ \\
\hline 36 & $\begin{array}{c}\mathbf{1 . 0 2} \\
{[0.51]}\end{array}$ & $\begin{array}{c}\mathbf{0 . 8 8} \\
{[0.46]}\end{array}$ & $\begin{array}{c}\mathbf{1 . 2 6} \\
{[0.45]}\end{array}$ & $\begin{array}{c}\mathbf{1 . 1 3} \\
{[0.53]}\end{array}$ \\
\hline 72 & $\begin{array}{c}\mathbf{0 . 7 1} \\
{[0.38]}\end{array}$ & $\begin{array}{c}\mathbf{0 . 5 5} \\
{[0.33]}\end{array}$ & $\begin{array}{c}\mathbf{0 . 8 7} \\
{[0.34]}\end{array}$ & $\begin{array}{c}\mathbf{0 . 8 3} \\
{[0.32]}\end{array}$ \\
\hline
\end{tabular}



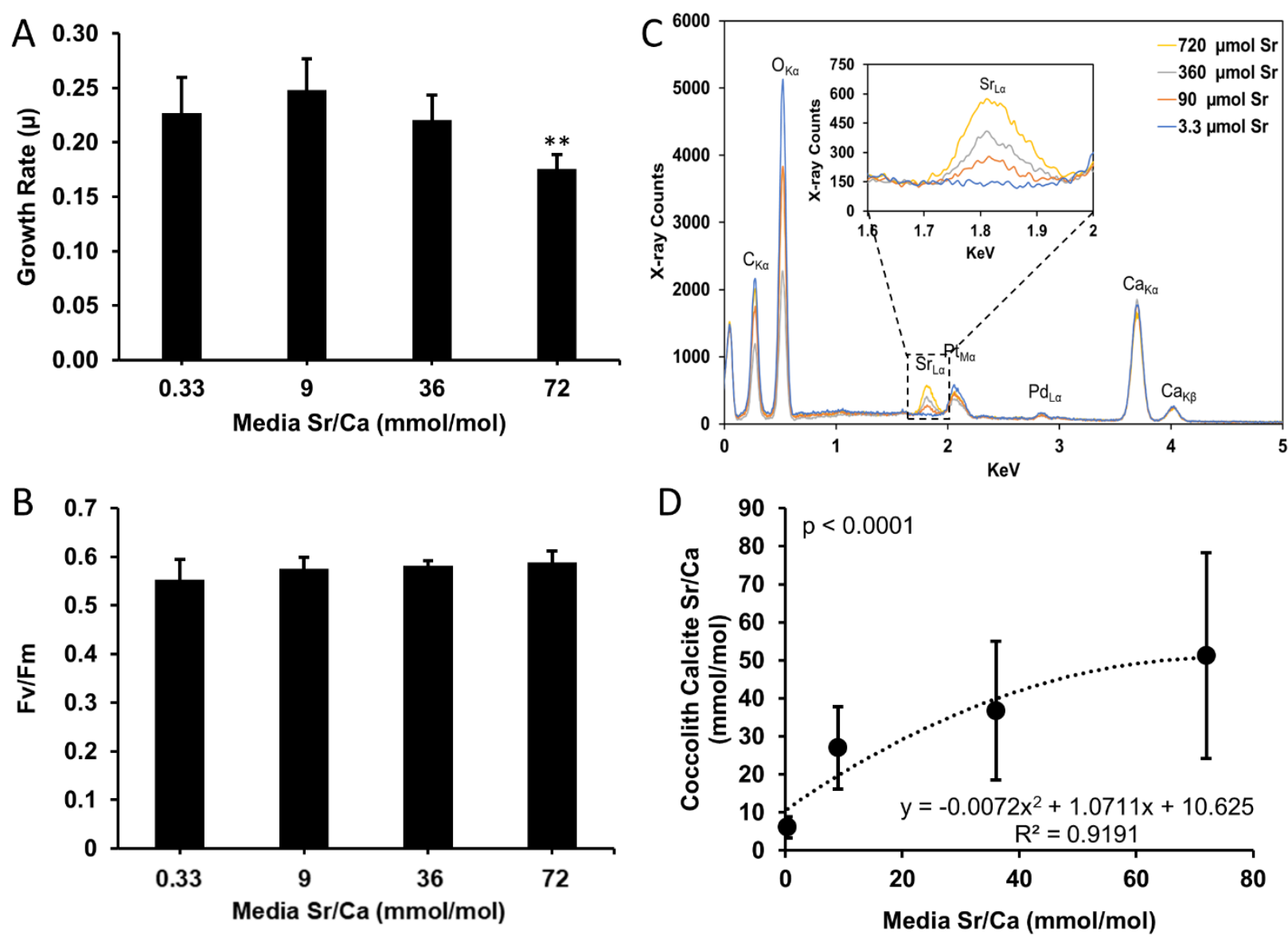

Figure 1. Growth and physiology unaffected by $\mathrm{Sr}$ incorporation when grown in deplete and enriched $\mathrm{Sr}$ media

(A) Maximum growth rate $(\mu)$ of S. apsteinii determined over $10 \mathrm{~d}$ in deplete, ambient, or enriched $\mathrm{Sr}$ treatments $(\mathrm{N}=4$ independent replicates for each $\mathrm{Sr}$ treatment $\pm \mathrm{SD})$. Cells grown in $72 \mathrm{mmol} / \mathrm{mol} \mathrm{Sr} / \mathrm{Ca}$ had a significantly lower growth rate $(\mathrm{p}<0.01$; student's t-test $)$ and cells grown in $142 \mathrm{mmol} / \mathrm{mol}$ failed to grow. (B) Quantum yield of photosystem II $\left(\mathrm{F}_{\mathrm{v}} / \mathrm{F}_{\mathrm{m}}\right)$ of darkadapted $S$. apsteinii cells grown under the same $\mathrm{Sr} / \mathrm{Ca}$ treatments showed no significant difference $(\mathrm{N}=4$ independent replicates for all $\mathrm{Sr}$ treatments $\pm \mathrm{SD}$, student's t-test). (C) Example EDS spectra showing increased $\mathrm{Sr}$ incorporation for $S$. apsteinii coccoliths grown in deplete, ambient, and enriched Sr. Insert: detail of the EDS spectra showing $\mathrm{Sr}$ peaks among $\mathrm{Sr}$ treatments. (D) Average $\mathrm{Sr} / \mathrm{Ca}( \pm \mathrm{SD})$ of $S$. apsteinii calcite increases with media $\mathrm{Sr} / \mathrm{Ca}$ $\mathrm{mmol} / \mathrm{mol}$. Lopadoliths and muroliths were combined resulting in 64-77 coccoliths for each treatment. The data were fit with a polynomial relationship $\left(r^{2}=0.92\right)$ and significant differences were determined between all Sr treatments $(p<0.001$, ANOVA with Dunn's Pairwise Comparison). 

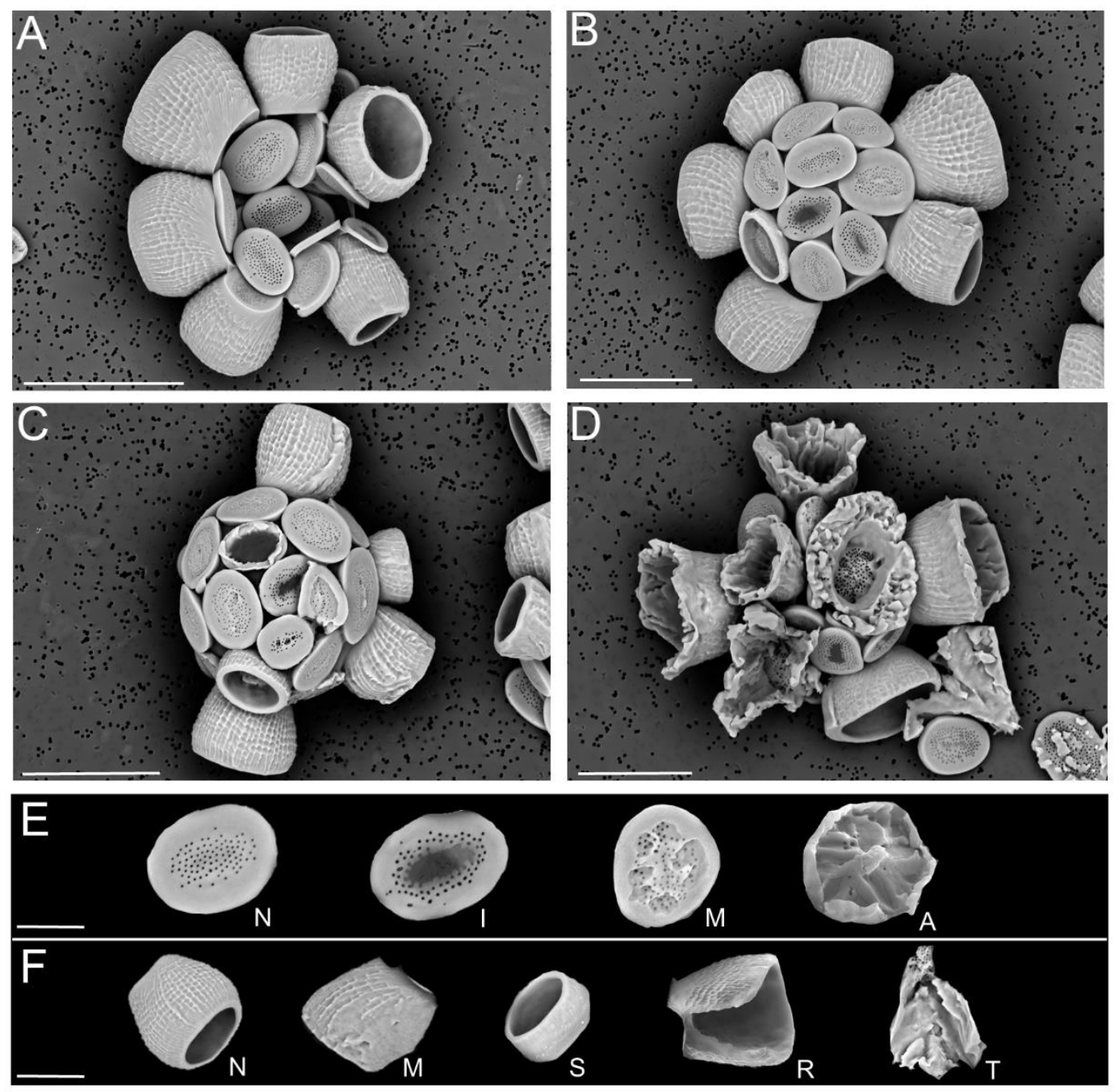

\section{Figure 2. Effect of Sr on S. apsteinii coccolith morphology}

SEM images acquired with an electron backscatter detector showing the effects of (A) deplete, (B) ambient, and (C,D) high ( $36 \mathrm{mmol} / \mathrm{mol} \mathrm{Sr}$ and $72 \mathrm{mmol} / \mathrm{mol} \mathrm{Sr} / \mathrm{Ca}$ respectively) $\mathrm{Sr}$ on $S$. apsteinii coccolith morphology. Scale bars represent $20 \mu \mathrm{m}$. (E) Examples of murolith morphology scoring categories from left to right: normal, incomplete, malformed, and aberrant. Scale bar represents $5 \mu \mathrm{m}$. (F) Examples of lopadolith morphology scoring categories from left to right: normal, malformed (minor malfunctions commonly seen in control cultures), Type $\mathrm{S}$ (a short lopadolith with normal morphology), Type R (longitudinal cleavage or sharp edging of lopadolith tip), and Type T (aberrant, completely disorganized calcite). 

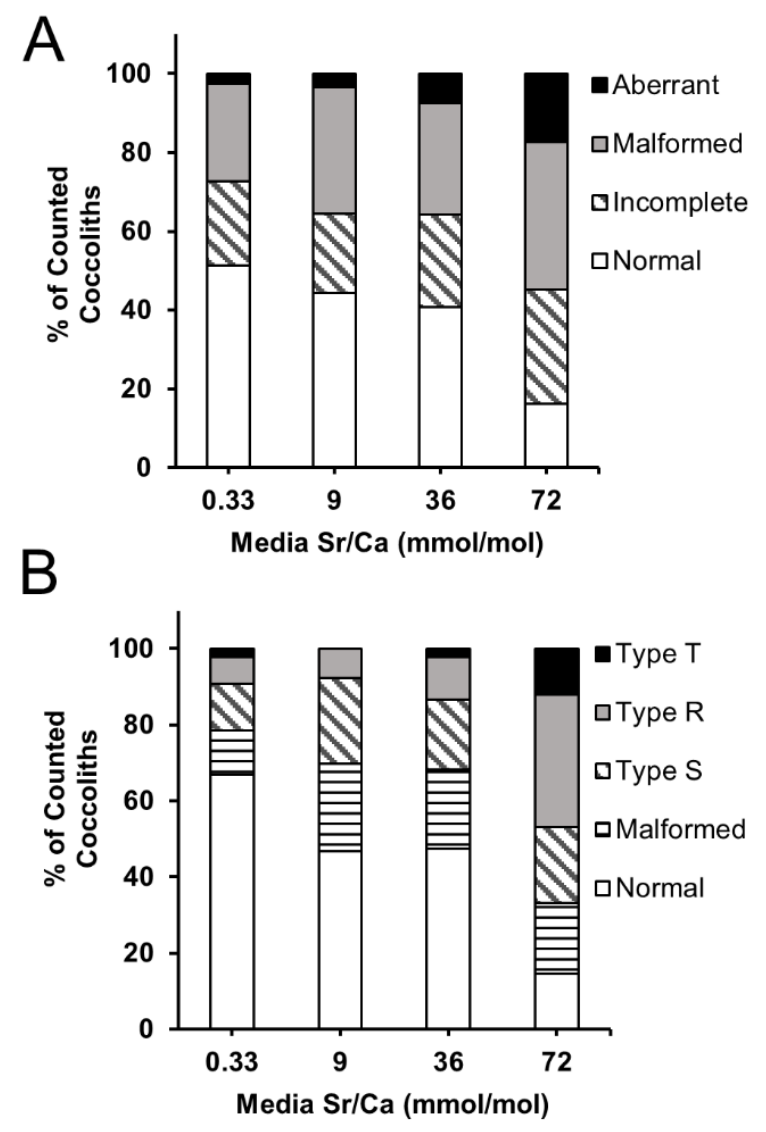

Figure 3. Increased $\mathrm{Sr}$ causes an increase in malformed and aberrant coccoliths produced by $S$. apsteinii

(A) Percentage of normal, incomplete, malformed, and aberrant S. apsteinii muroliths in coccospheres of cells grown in deplete, ambient, and high $\mathrm{Sr}( \pm \mathrm{SD})$. Percentages represent the average for 4 experimental replicates in which 62-85 muroliths from 40 cells were scored for morphology type and divided by the total muroliths counted for that replicate. The frequency of normal muroliths was significantly higher in the $0.33 \mathrm{mmol} / \mathrm{mol} \mathrm{Sr} / \mathrm{Ca}$ compared to all others, while cells grown in the $72 \mathrm{mmol} / \mathrm{mol} \mathrm{Sr} / \mathrm{Ca}$ treatment produced a significantly higher number of aberrant muroliths ( $\mathrm{p}<0.001$, ANOVA with Tukey's Pairwise Comparison). (B) Percentage of normal, malformed, Type S, Type R, and Type T S. apsteinii lopadoliths (see Fig. 2) from cells grown in deplete, ambient, and high $\mathrm{Sr}$ (37-61 lopadoliths from 40 cells from 4 replicate cultures were scored for each $\mathrm{Sr}$ treatment $\pm \mathrm{SD}$ ). The $72 \mathrm{mmol} / \mathrm{mol} \mathrm{Sr} / \mathrm{Ca}$ treatment had a significantly higher number of Type $\mathrm{R}$ and Type T lopadoliths $(\mathrm{p}<0.001$ and $\mathrm{p}<0.05$, respectively, ANOVA with Tukey's Pairwise Comparison). The $0.33 \mathrm{mmol} / \mathrm{mol} \mathrm{Sr} / \mathrm{Ca}$ treatment had a significantly higher frequency of normal lopadoliths compared to other $\mathrm{Sr}$ treatments $(\mathrm{p}<0.001$, ANOVA with Tukey's Pairwise Comparison). See Table 1 for details. 


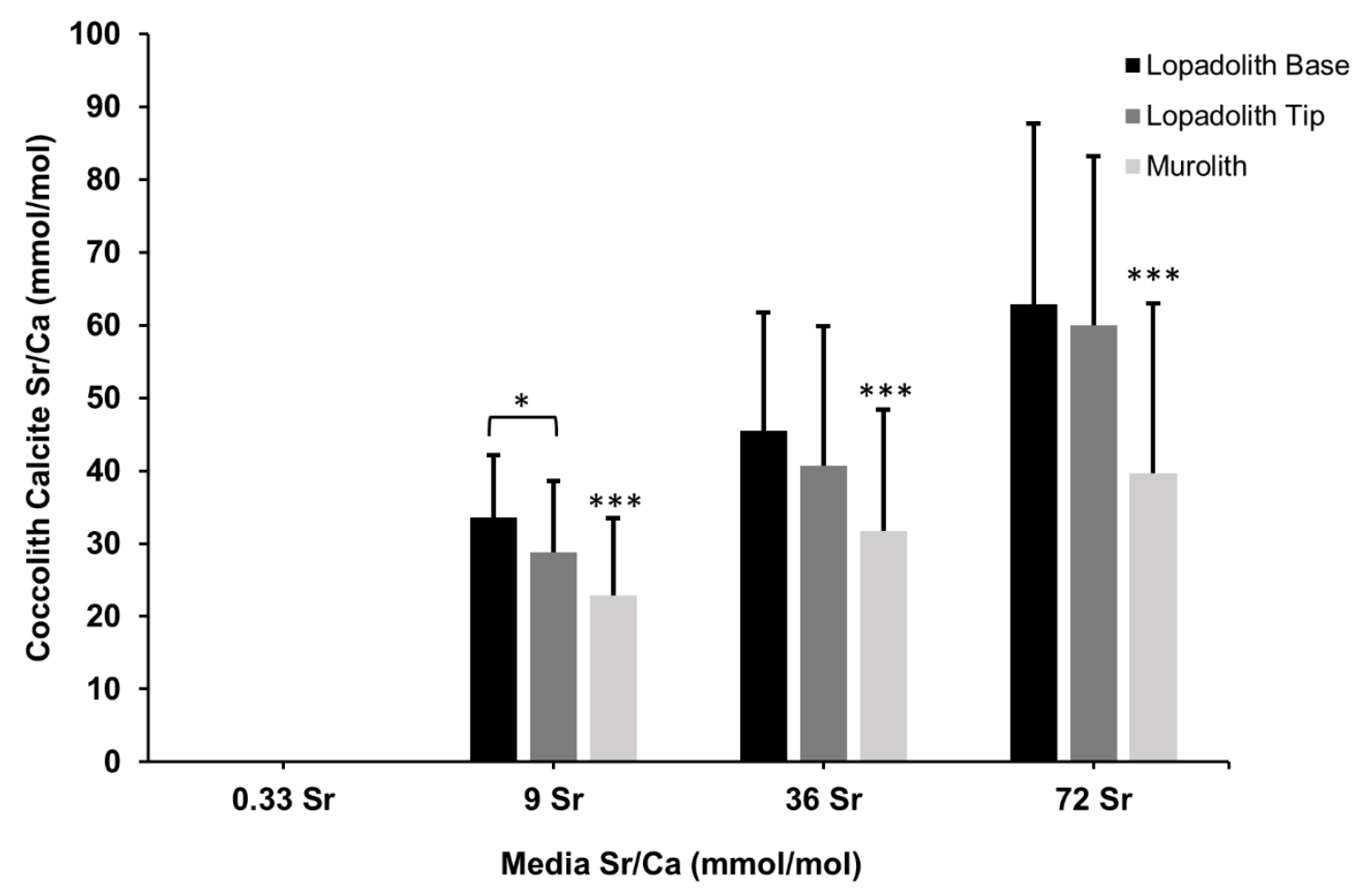

Figure 4. Average $\mathrm{Sr} / \mathrm{Ca} \mathrm{mmol} / \mathrm{mol}$ in $\mathrm{S}$. apsteinii coccoliths by morphotype in response to increasing media $[\mathrm{Sr}]$

Average calcite $\mathrm{Sr} / \mathrm{Ca} \mathrm{mmol} / \mathrm{mol}$ values $\left( \pm \mathrm{SD}, \mathrm{N}_{\text {muroliths }}=63-75 ; \mathrm{N}_{\text {lopadolith base }}=29-36 ; \mathrm{N}_{\text {lopadolith }}\right.$ tip $=29-37$ coccoliths from each experimental treatment) were calculated using Eq. 1 for muroliths and lopadoliths. The $\mathrm{Sr} / \mathrm{Ca} \mathrm{mmol} / \mathrm{mol}$ ratio was significantly higher in lopadoliths vs muroliths in the ambient ( $p<0.001$, t-test) and the two enriched $\mathrm{Sr}$ treatments ( $\mathrm{p}<0.001$, $\mathrm{t}$-test). There was a significantly higher $\mathrm{Sr} / \mathrm{Ca}$ in the lopadolith base compared to tip in ambient $\mathrm{Sr}$ conditions ( $p<0.05$, Student's t-test). There was no significant difference in $\mathrm{Sr}$ content between base and tip for the two enriched Sr treatments. The EDS limit of detection (LOD) for Sr was calculated to be $2.29 \mathrm{mmol} / \mathrm{mol} \mathrm{Sr} / \mathrm{Ca}$. Calculated calcite $\mathrm{Sr} / \mathrm{Ca}$ values for cells from the 0.33 $\mathrm{Sr} / \mathrm{Ca} \mathrm{mmol} / \mathrm{mol}$ treatment were technically at or below LOD for the EDS method and were not further analyzed. See Table 2 for details. 


\subsection{Citations}

Addadi, L., Joester, D., Nudelman, F. and Weiner, S. (2006) Mollusk shell formation: A source of new concepts for understanding biomineralization processes. Chem.: Eur. J. 12, 981987.

Balch, W. M. (2018) The Ecology, Biogeochemistry, and Optical Properties of Coccolithophores. Annu. Rev. Mar. Sci. 10, 71-98.

Borman, A. H., Dejong, E. W., Huizinga, M., Kok, D. J., Westbroek, P. and Bosch, L. (1982) The role in $\mathrm{CaCO}_{3}$ crystallization of an acid $\mathrm{Ca}^{2+}$ binding polysaccharide associated with coccoliths of Emiliania-huxleyi. Eur. J. Biochem. 129, 179-183.

Bourinet, E., Zamponi, G. W., Stea, A., Soong, T. W., Lewis, B. A., Jones, L. P., Yue, D. T. and Snutch, T. P. (1996) The alpha(1E) calcium channel exhibits permeation properties similar to low-voltage-activated calcium channels. J. Neurosci. 16, 4983-4993.

Brownlee, C. and Taylor, A. (2004) Calcification in coccolithophores: A cellular perspective. In: Coccolithophores: from Molecular Processes to Global Impact (eds H.R. Thierstein and J.R. Young). Springer, Berlin. pp. 31-49.

Brownlee, C., Wheeler, G. L. and Taylor, A. R. (2015) Coccolithophore biomineralization: New questions, new answers. Semin. Cell Dev. Biol. 46, 11-16.

Daniels, C. J., Poulton, A. J., Balch, W. M., Maranon, E., Adey, T., Bowler, B. C., Cermeno, P., Charalampopoulou, A., Crawford, D. W., Drapeau, D., Feng, Y. Y., Fernandez, A., Fernandez, E., Fragoso, G. M., Gonzalez, N., Graziano, L. M., Heslop, R., Holligan, P. M., Hopkins, J., Huete-Ortega, M., Hutchins, D. A., Lam, P. J., Lipsen, M. S., LopezSandoval, D. C., Loucaides, S., Marchetti, A., Mayers, K. M. J., Rees, A. P., Sobrino, C., Tynan, E. and Tyrre, T. (2018) A global compilation of coccolithophore calcification rates. Earth Syst. Sci. Data 10, 1859-1876.

Davis, T. A., Volesky, B. and Mucchi, A. (2003) A review of the biochemistry of heavy metal biosorption by brown algae. Water Res. 37, 4311-4330.

De Nooijer, L. J., Spero, H. J., Erez, J., Bijma, J. and Reichart, G. J. (2014) Biomineralization in perforate foraminifera. Earth-Sci. Rev. 135, 48-58.

De Villiers, S. (1999) Seawater strontium and Sr/Ca variability in the Atlantic and Pacific oceans. Earth Planet. Sc. Lett. 171, 623-634.

Drescher, B., Dillaman, R. M. and Taylor, A. R. (2012) Coccolithogenesis in Scyphosphaera apsteinii (Prymnesiophyceae). J. Phycol. 48, 1343-1361.

Durak, G. M., Brownlee, C., and Wheeler, G. L. (2017) The role of the cytoskeleton in biomineralisation in haptophyte algae. Sci. Rep. 7:15409. 
Fichtinger-Schepman, A. M., Kamerling, J. P., Versluis, C. and Vliegenthart, J. F. G. (1981) Structural studies of the methylated, acidic polysaccharide associated with coccoliths of Emiliania-huxleyi (Lohmann) Kamptner. Carbohydr. Res. 93, 105-123.

Flores, J. A., Sierro, F. J., Frances, G., Vazquez, A. and Zamarreno, I. (1997) The last 100,000 years in the western Mediterranean: Sea surface water and frontal dynamics as revealed by coccolithophores. Mar. Micropaleontol. 29, 351-366.

Fowler, N., Tomas, C., Baden, D., Campbell, L. and Bourdelais, A. (2015) Chemical analysis of Karenia papilionacea. Toxicon. 101, 85-91.

Gafar, N. A., Eyre, B. D. and Kai, G. S. (2019) A comparison of species specific sensitivities to changing light and carbonate chemistry in calcifying marine phytoplankton. Sci. Rep. 9:2486, 1-12.

Gal, A., Sviben, S., Wirth, R., Schreiber, A., Lassalle-Kaiser, B., Faivre, D. and Scheffel, A. (2017) Trace-element incorporation into intracellular pools uncovers calcium-pathways in a coccolithophore. $A d v . S c i .4,5$.

Grant, G. T., Morris, E. R., Rees, D. A., Smith, P. J. C. and Thom, D. (1973) Biological interactions between polysaccharides and divalent cations - egg-box model. FEBS Lett. 32, 195-198.

Grovenor, C. R. M., Smart, K. E., Kilburn, M. R., Shore, B., Dilworth, J. R., Martin, B., Hawes, C. and Rickaby, R. E. M. (2006) Specimen preparation for NanoSIMS analysis of biological materials. Appl. Surf. Sci. 252, 6917-6924.

Henriksen, K. and Stipp, S. L. S. (2009) Controlling biomineralization: The effect of solution composition on coccolith polysaccharide functionality. Cryst. Growth Des. 9, 2088-2097.

Henriksen, K., Stipp, S. L. S., Young, J. R. and Marsh, M. E. (2004) Biological control on calcite crystallization: AFM investigation of coccolith polysaccharide function. Am. Min. 89, 1709-1716.

Hermoso, M. (2014) Coccolith-derived isotopic proxies in palaeoceanography: where geologists need biologists. Cryptogamie Algol. 35, 323-351.

Hermoso, M., Lefeuvre, B., Minoletti, F. and De Rafelis, M. (2017) Extreme strontium concentrations reveal specific biomineralization pathways in certain coccolithophores with implications for the Sr/Ca paleoproductivity proxy. Plos One 12: e018565, 16.

Hopkins, J. and Balch, W. M. (2018) A new approach to estimating coccolithophore calcification rates from space. J. Geophys. Res.-Biogeo. 123, 1447-1459.

Ishii, T., Matsunaga, T., Pellerin, P., O'neill, M. A., Darvill, A. and Albersheim, P. (1999) The plant cell wall polysaccharide rhamnogalacturonan II self-assembles into a covalently cross-linked dimer. J. Biol. Chem. 274, 13098-13104. 
Kester, D. R., Duedall, I. W., Connors, D. N. and Pytkowicz, R. M. (1967) Preparation of artificial seawater. Limnol. Oceanogr. 12, 176-+.

Krumhardt, K. M., Lovenduski, N. S., Iglesias-Rodriguez, M. D. and Kleypas, J. A. (2017) Coccolithophore growth and calcification in a changing ocean. Prog. Oceanogr. 159, 276-295.

Kucerka, N., Papp-Szabo, E., Nieh, M. P., Harroun, T. A., Schooling, S. R., Pencer, J., Nicholson, E. A., Beveridge, T. J. and Katsaras, J. (2008) Effect of cations on the structure of bilayers formed by lipopolysaccharides isolated from Pseudomonas aeruginosa PAO1. J. Phys. Chem. B 112, 8057-8062.

Langer, G., De Nooijer, L. J. and Oetjen, K. (2010) On the role of the cytoskeleton in coccolith morphogenesis: The effect of cytoskeleton inhibitors. J. Phycol. 46, 1252-1256.

Langer, G., Gussone, N., Nehrke, G., Riebesell, U., Eisenhauer, A., Kuhnert, H., Rost, B., Trimborn, S. and Thoms, S. (2006) Coccolith strontium to calcium ratios in Emiliania huxleyi: The dependence on seawater strontium and calcium concentrations. Limnol. Oceanogr. 51, 310-320.

Littlewood, J. L., Shaw, S., Peacock, C. L., Bots, P., Trivedi, D. and Burke, I. T. (2017) Mechanism of enhanced strontium uptake into calcite via an amorphous calcium carbonate crystallization pathway. Cryst. Growth Des. 17, 1214-1223.

Mackinder, L., Wheeler, G., Schroeder, D., Riebesell, U. and Brownlee, C. (2010) Molecular mechanisms underlying calcification in coccolithophores. Geomicrobiol. J. 27, 585-595.

Marsh, M. E. (1994) Polyanion-mediated mineralization - assembly and reorganization of acidic polysaccharides in the golgi system of a coccolithophorid alga during mineral deposition. Protoplasma 177, 108-122.

Marsh, M. E. (2000) Polyanions in the $\mathrm{CaCO}_{3}$ mineralization of coccolithophores. In: Biomineralization: from biology to biotechnology and medical application. (ed E. Bauerlein). Wiley-VCH, Weinheim. pp. 251-268.

Marsh, M. E. (2003) Regulation of $\mathrm{CaCO}_{3}$ formation in coccolithophores. Comp. Biochem. Phys. B 136, 743-754.

Marsh, M. E., Ridall, A. L., Azadi, P. and Duke, P. J. (2002) Galacturonomannan and Golgiderived membrane linked to growth and shaping of biogenic calcite. J. Struct. Biol. 139, $39-45$.

Milliman, J. D. (1993) Production and Accumulation of Calcium-Carbonate in the Ocean Budget of a Nonsteady State. Global Biogeochem. Cy. 7, 927-957.

Muller, M. N., Krabbenhoft, A., Vollstaedt, H., Brandini, F. P. and Eisenhauer, A. (2018) Stable isotope fractionation of strontium in coccolithophore calcite: Influence of temperature and carbonate chemistry. Geobiology 16, 297-306. 
Outka, D. E. and Williams, D. C. (1971) Sequential Coccolith Morphogenesis in Hymenomonas carterae. J. Protozool. 18, 285-297.

Payne, V. E., Rickaby, R. E. M., Benning, L. G. and Shaw, S. (2008) Calcite crystal growth orientation: implications for trace metal uptake into coccoliths. Mineral. Mag. 72, 269272.

Prentice, K., Dunkley Jones, T., Lees, J., Young, J., Bown, P., Langer, G., Fearn, S. and Eimf (2014) Trace metal $(\mathrm{Mg} / \mathrm{Ca}$ and $\mathrm{Sr} / \mathrm{Ca})$ analyses of single coccoliths by Secondary Ion Mass Spectrometry. Geochim. Cosmochim. Ac. 146, 90-106.

Rickaby, R. E. M., Schrag, D. P., Zondervan, I. and Riebesell, U. (2002) Growth rate dependence of $\mathrm{Sr}$ incorporation during calcification of Emiliania huxleyi. Global Biogeochem. Cy. 16, 8.

Rodriguez-Contreras, A., Lv, P., Zhu, J., Kim, H. J. and Yamoah, E. N. (2008) Effects of strontium on the permeation and gating phenotype of calcium channels in hair cells. $J$. Neurophysiol. 100, 2115-2124.

Rodriguez-Contreras, A. and Yamoah, E. N. (2003) Effects of permeant ion concentrations on the gating of L-type Ca2+ channels in hair cells. Biophys. J. 84, 3457-3469.

Saavedra-Pellitero, M., Baumann, K. H., Ullermann, J. and Lamy, F. (2017) Marine Isotope Stage 11 in the Pacific sector of the Southern Ocean; a coccolithophore perspective. Quat. Sci. Rev. 158, 1-14.

Stevenson, E. I., Hermoso, M., Rickaby, R. E. M., Tyler, J. J., Minoletti, F., Parkinson, I. J., Mokadem, F. and Burton, K. W. (2014) Controls on stable strontium isotope fractionation in coccolithophores with implications for the marine Sr cycle. Geochim. Cosmochim. Ac. 128, 225-235.

Stoll, H. M., Rosenthal, Y. and Falkowski, P. (2002a) Climate proxies from Sr/Ca of coccolith calcite: Calibrations from continuous culture of Emiliania huxleyi. Geochim. Cosmochim. Ac. 66, 927-936.

Stoll, H. M. and Schrag, D. P. (2000) Coccolith Sr/Ca as a new indicator of coccolithophorid calcification and growth rate. Geochem. Geophys. Geosyst. 1, 24.

Stoll, H. M., Shimizu, N., Archer, D. and Ziveri, P. (2007a) Coccolithophore productivity response to greenhouse event of the Paleocene-Eocene Thermal Maximum. Earth Planet. Sc. Lett. 258, 192-206.

Stoll, H. M., Ziveri, P., Geisen, M., Probert, I. and Young, J. R. (2002b) Potential and limitations of $\mathrm{Sr} / \mathrm{Ca}$ ratios in coccolith carbonate: new perspectives from cultures and monospecific samples from sediments. Philos. T. R. Soc. A 360, 719-747. 
Stoll, H. M., Ziveri, P., Shimizu, N., Conte, M. and Theroux, S. (2007b) Relationship between coccolith $\mathrm{Sr} / \mathrm{Ca}$ ratios and coccolithophore production and export in the Arabian Sea and Sargasso Sea. Deep-Sea Res. Pt. II 54, 581-600.

Sucheras-Marx, B., Giraud, F., Simionovici, A., Daniel, I. and Tucoulou, R. (2016) Perspectives on heterococcolith geochemical proxies based on high-resolution X-ray fluorescence mapping. Geobiology 14, 390-403.

Sun, S. Y., Liu, M. X., Nie, X. Q., Dong, F. Q., Hu, W. Y., Tan, D. Y. and Huo, T. T. (2018) A synergetic biomineralization strategy for immobilizing strontium during calcification of the coccolithophore Emiliania huxleyi. Environ. Sci. Pollut. R. 25, 22446-22454.

Taylor, A. R., Brownlee, C., Wheeler, G. and Annual, R. (2017) Coccolithophore Cell Biology: Chalking Up Progress. Annu. Rev. Mar. Sci. 9, 283-310.

Walker, C. E., Heath, S., Salmon, D. L., Smirnoff, N., Langer, G., Taylor, A. R., Brownlee, C. and Wheeler, G. L. (2018a) An Extracellular Polysaccharide-Rich Organic Layer Contributes to Organization of the Coccosphere in Coccolithophores. Front. Mar. Sci. 5, 12.

Walker, C. E., Taylor, A. R., Langer, G., Durak, G. M., Heath, S., Probert, I., Tyrrell, T., Brownlee, C. and Wheeler, G. L. (2018b) The requirement for calcification differs between ecologically important coccolithophore species. New Phytol. 220, 147-162.

Wasylenki, L. E., Dove, P. M., Wilson, D. S. and De Yoreo, J. J. (2005) Nanoscale effects of strontium on calcite growth: An in situ AFM study in the absence of vital effects. Geochim. Cosmochim. Ac. 69, 3017-3027.

Westbroek, P., Dejong, E. W., Vanderwal, P., Borman, A. H., Devrind, J. P. M., Kok, D., Debruijn, W. C. and Parker, S. B. (1984) Mechanism of calcification in the marine alga Emiliania-huxleyi. Philos. Trans. R. Soc. Lond. B Biol. Sci. 304, 435-\&.

Woodward, C. and Davidson, E. A. (1968) Structure-function relationships of protein polysaccharide complexes - specific ion-binding properties. Proc. Natl. Acad. Sci. U.S.A. 60, 201-205.

Young, J. R., Davis, S. A., Bown, P. R. and Mann, S. (1999) Coccolith ultrastructure and biomineralisation. J. Struct. Biol. 126, 195-215.

Young, J. R., Poulton, A. J. and Tyrrell, T. (2014) Morphology of Emiliania huxleyi coccoliths on the northwestern European shelf - is there an influence of carbonate chemistry? Biogeosciences 11, 4771-4782. 